УДК 342.9:347(77+78)

DOI https://doi.org/10.32849/2663-5313/2019.8.17

\title{
Олена Коротун,
}

канд. юрид.наук, докторант

Науково-дослідного інституту публічного права

\section{Олександр Світличний,}

докт. юрид. наук, дочент,

професор кафедри цивільного та господарського права

Начіонального університету біоресурсів і природокористування України

\section{ПОНЯТТЯ ТА СТРУКТУРА АДМІНІСТРАТИВНО- ПРАВОВОГО ЗАБЕЗПЕЧЕННЯ ОХОРОНИ ПРАВ СУБ’ЄКТІВ ІНТЕЛЕКТУАЛЬНОЇ ВЛАСНОСТІ}

Стаття присвячена поняттю, структурі адміністративно-правового забезпечення охорони прав суб'єктів інтелектуальної власності. Відсутність теоретичних узагальнень та відповідних практичних рекомендацій негативно впливають на формування та розвиток науки адміністративного права, охорону особистих немайнових та (або) майнових прав суб'єктів права інтелектуальної власності. Відповідно, відсутність основоположної теорії адміністративно-правового забезпечення охорони прав суб'єктів інтелектуальної власності, сучасне бачення розвитку суспільних відносин у досліджуваній сфері до иього часу так і не отримали свого наукового втілення.

Провідну роль у регулюванні відносин у сфері охорони прав суб'єктів інтелектуальної власності відіграє конституиійне право. Особисті немайнові та майнові права інтелектуальної власності підлягають правовій охороні нормами приватного і публічного права, провідну роль серед яких відіграє иивільне і адміністративне право - дві фундаментальні галузі національного права. Усе ие дістає відображення у диспозитивному та імперативному методі правового регулювання, які являють собою найтиповіші прийоми правового регулювання у досліджуваній сфері.

Звертається увага, що адміністративно-правове забезпечення суспільних відносин у сфері охорони прав суб'єктів інтелектуальної власності є спещифічною владною діяльністю органів публічної адміністрачії, їх посадових осіб, які наділені владними повноваженнями у сфері забезпечення охорони інтелектуальної власності. Такими публічними органами у досліджуваній сфері насамперед $є$ Міністерство економічного розвитку і торгівлі України, «Укрпатент», АМКУ та інші уповноважені органи публічної адміністрачії, які наділені повноваженнями щодо реалізації, охорони та розвитку відносин у сфері охорони інтелектуальної власності. Діяльність публічної адміністрачії передбачає використання адміністративно-правових норм, які являють собою різновид правових норм й відіграють важливу роль у регулюванні суспільних відносин у сфері охорони права інтелектуальної власності, а також виконують одну з основних функиій щодо забезпечення охорони суб'єктивних прав правовласників об'єктів права інтелектуальної власності, захисту суб'єктів господарської діяльності, прав і законних інтересів споживачів. Особливо важливим є визначення сфер впливу правового регулювання та реалізаиії норм адміністративного права органами публічної адміністраиіі.

Окрема увага приділяється змісту та структурі адміністративно-правового забезпечення, розкривається структура та надається авторське визначення поняття «адміністративно-правове забезпечення».

Ключові слова: суб'єкти, охорона, права, інтелектуальна власність, поняття, адміністративноправове регулювання, структура.

Постановка проблеми. Суспільні відносини у сфері інтелектуальної власності зумовлюють організуючий вплив держави з метою задоволення потреб суспільства, яке під впливом нових соціально-економічних викликів та загроз потребує гарантованої Конституцією України охорони суб'єктивних прав правовласників об'єктів права інтелектуальної власності та інтер- есів держави. Першоосновою цього процесу повинно стати наукове дослідження поняття «адміністративно-правове забезпечення» як важливої юридичної категорії науки адміністративного права.

Незважаючи на загальний інтерес до адміністративно-правового забезпечення у різних сферах правового регулювання суспільних відносин, у рамках проблематики 
дослідження питання щодо поняття і аналізу сутності адміністративно-правового забезпечення охорони прав суб'єктів інтелектуальної власності у вітчизняній юридичній науці практично не досліджувалось.

Аналіз останніх досліджень. Теоретикометодологічним підгрунтям написання статті послужили праці: А. Авер'янова, В. Галунька, С. Діденка, Т. Коломоєць, В. Колпакова, В. Курила, Г. Римарчук, О. Нікитенка, С. Стеценка та ін. Не заперечуючи вагомого внеску вказаних вчених, зазначимо, що натепер практично відсутні наукові дослідження, присвячені адміністративно-правовому забезпеченню охорони прав суб'єктів інтелектуальної власності. Відсутність теоретичних узагальнень та відповідних практичних рекомендацій негативно впливають на формування та розвиток науки адміністративного права, охорону особистих немайнових та (або) майнових прав суб'єктів права інтелектуальної власності. Відповідно, відсутність основоположної теорії адміністративно-правового забезпечення охорони прав суб'єктів інтелектуальної власності, сучасне бачення розвитку суспільних відносин у досліджуваній сфері до цього часу так і не отримали свого наукового втілення, що й зумовлює актуальність цієї статті.

Мета цієї статті полягає в тому, щоб з огляду на доктринальні підходи та правове регулювання розкрити поняття, структуру адміністративно-правового забезпечення охорони прав суб'єктів інтелектуальної власності.

Виклад основного матеріалу. Забезпечуючи охорону суб'єктивних прав правовласників об'єктів права інтелектуальної власності, держава забезпечує охорону інтелектуальної власності, дотримання правового порядку в суспільстві, встановлює заборону на незаконне використання майнового та особистого немайнового права інтелектуальної власності, а у разі встановлення факту порушення притягує винних осіб до юридичної відповідальності.

У чинних вітчизняних законодавчих актах є перелік об'єктів права інтелектуальної власності, у разі незаконного використання яких порушуються суб'єктивні права правовласників об'єктів права інтелектуальної власності [1, с. 6]. Як зазначає М. Потоцький, суб'єктивне право інтелектуальної власності - юридично визначена можливість особи задовольнити свої немайнові (особисті) та майнові потреби щодо об'єктів права інтелектуальної власності, які охороняються державою [2, с. 6].
Суб'єктивні права учасників правовідносин у сфері інтелектуальної власності пов'язані з володінням, користуванням і розпорядженням майновими правами інтелектуальної власності, особистими немайновими правами інтелектуальної власності, які пов'язані з правом особи на визнання результатів творчої інтелектуальної діяльності, правом перешкоджати будь-якому посяганню на право інтелектуальної власності, а також іншими особистими немайновими правами інтелектуальної власності, які встановлені законом і підлягають правовій охороні.

Особисті немайнові та майнові права інтелектуальної власності підлягають правовій охороні нормами приватного і публічного права, провідну роль серед яких відіграє цивільне і адміністративне право - дві фундаментальні галузі національного права. Усе це достає відображення у диспозитивному та імперативному методі правового регулювання, які являють собою найтиповіші прийоми правового регулювання у дослідженій сфері. Проте було б спрощенням обмежитися тільки згаданими галузями права. Юридичну першооснову в охороні майнових прав інтелектуальної власності, як і для інших галузей національного права, становить конституційне право.

При цьому правове регулювання як спеціально-юридичний вплив у будь-якому разі пов'язане з встановленням конкретних прав та обов'язків суб'єктів, з прямими приписами про належне і можливе, а правовий вплив не завжди. Якщо перше означає реалізацію правових норм через правовідносини, то друге - не обов’язково. Звідси - правове регулювання завжди означає і правовий вплив, але правовий вплив не завжди означає свідоме нормування суспільних відносин. У цьому сенсі регулювання - лише одна з форм впливу права на соціальні зв'язки, що охоплюе далеко не всі інші його форми [3, с. 27].

Необхідним елементом взаємодії держави і права $є$ юридичний обов'язок, у якому держава формулює свої вимоги до громадян. Юридичний обов'язок - це об’єктивно необхідна, встановлена законом міра належної поведінки. Першоприрода обов'язків така, що вони покликані бути зворотною стороною суб'єктивного права як стимулюючі засоби [4, с. 271].

У сфері забезпечення охорони прав суб'єктів інтелектуальної власності функціональне призначення права полягає як у забезпеченні реалізації права на результати творчої інтелектуальної діяльності, так і покладанні обов'язків на осіб приватного та публічного права. Тому з'ясування сутності «адміністративно-правового забезпечення» 
та його елементів залишається актуальним науковим напрямом дослідження.

Перш ніж перейди до аналізу адміністративно-правового забезпечення охорони прав суб’єктів інтелектуальної власності, важливо зауважити, що широта окресленого питання свідчить, що залежно від сфери регулювання відносин у юридичній науці ми можемо знайти різні підходи до змісту визначення поняття «адміністративно-правове забезпечення». Теоретична конструкція вказаного поняття спонукає науковців розглядати досліджувану категорію як через з'ясування співвідношення категорії «адміністративноправове забезпечення» 3 поняттям «адміністративно-правове регулювання»; «правове регулювання» та «правове забезпечення»; через сутнісну характеристику термінів «право» та «забезпечувати»; через «режим» забезпечення; розгляд у вузькому та широкому розумінні.

Враховуючи специфіку дослідження, звернемо свою увагу на наукову позицію Г. Римарчук, на думку якої адміністративноправове забезпечення права інтелектуальної власності - це здійснення державою за допомогою правових норм, приписів і сукупності засобів упорядкування суспільних відносин, їх юридичне закріплення, охорона, реалізація та розвиток $[5$, с. 8$]$.

Виходячи зі специфіки охорони особистого немайнового та (або) майнового права інтелектуальної власності, яке є непорушним і охороняється державою, адміністративно-правове забезпечення - це перш за все регламентована адміністративно-правовими нормами діяльність уповноважених суб'єктів публічної адміністрації, що спрямована на реалізацію конституційних гарантій охорони та захисту моральних і матеріальних інтересів правовласників об'єктів права інтелектуальної власності та інших учасників суспільних відносин, що виникають у зв'язку з різними видами інтелектуальної діяльності.

Об'єктом адміністративно-правового забезпечення є суспільні відносини у сфері охорони прав суб'єктів інтелектуальної власності, що потребує правового регулювання та реалізації норм адміністративного права суб'єктами публічної адміністрації.

Суб'єктами адміністративно-правового забезпечення у сфері охорони прав суб'єктів інтелектуальної власності є спеціально уповноважені суб'єкти публічної адміністрації, які наділені владними повноваженнями, правами та обов'язками, що встановлені адміністративно-правими нормами. Під суб'єктами публічної адміністрації ми розуміємо широке коло уповноважених суб'єктів, які наділені різними за змістом і обсягом адміністратив- ними повноваженнями. Поряд 3 органами виконавчої влади в публічному управлінні задіяні й інші суб'єкти, які організаційно не входять до системи органів виконавчої влади, а також як окремі фізичні особи, так i юридичні особи публічного та приватного права [6, с. 215].

Отже, адміністративно-правове забезпечення суспільних відносин у сфері охорони прав суб'єктів інтелектуальної власності є специфічною владною діяльністю органи публічної адміністрації, їх посадових осіб, які наділені владними повноваженнями у сфері забезпечення охорони інтелектуальної власності.

Насамперед такими публічними органами у досліджуваній сфері є Міністерство економічного розвитку і торгівлі України, «Укрпатент», АМКУ та інші уповноважені органи публічної адміністрації, які наділені повноваженнями щодо реалізації, охорони та розвитку відносин у сфері охорони прав суб'єктів інтелектуальної власності. Водночас діяльність публічної адміністрації передбачає використання адміністративноправових норм, які являють собою різновид правових норм й відіграють важливу роль у регулюванні суспільних відносин у сфері охорони права інтелектуальної власності, виконують одну з основних функцій щодо забезпечення охорони суб'єктивних прав правовласників об'єктів права інтелектуальної власності, захисту суб'єктів господарської діяльності, прав і законних інтересів споживачів. Особливо важливим є визначення сфер впливу правового регулювання та реалізації норм адміністративного права органами публічної адміністрації. За допомогою адміністративно-правових норм, які виконують різноманітні функції, здійснюється правове регулювання у досліджуваній cферi.

С. Алексєєв зауважував, що правове регулювання - головне, вирішальне поняття правової дійсності, яка розглядається в динаміці 3 активно-дієвого боку, і пропонує розуміти це поняття у двох значеннях - вузькому та широкому. У вузькому вчений характеризував правове регулювання як «дію норм права (системи правових норм), інших спеціальних юридичних засобів на поведінку особи та на суспільні відносини з метою їх упорядкування та прогресивного розвитку» [7, с. 219].

Вказане свідчить, що в практичній діяльності з метою охорони права інтелектуальної власності уповноважені державою органи публічної адміністрації, наділені владними повноваженнями, в межах визначеної компетенції приймають обов'язкові для інших суб'єктів рішення, реалізуючи в правозасто- 
совній діяльності норми адміністративного права шляхом застосування диспозиції відповідної норми закону.

У результаті реалізації норм права виникають адміністративно-правові відносини, що урегульовані нормами адміністративного права, в яких сторони беруть участь як носії прав та обов'язків, установлених і забезпечених адміністративно-правовими приписами. Власне адміністративно-правові відносини у досліджуваній сфері, передбачають виділення їх певних видів. Ними є: регулятивні та правоохоронні; двосторонні або багатосторонні; за сферою виникнення; за станом взаємної підпорядкованості суб'єктів; вертикальні та горизонтальні правовідносини [8, с. 176-179].

Регулятивні правовідносини (позитивні функції адміністративного права) у досліджуваній сфері, перш за все, пов'язані з діяльністю органів публічної адміністрації, керівництвом нижчими структурами. Регулятивні правовідносини виникають і діють під час дотримання громадянами та суб'єктами господарської діяльності правомірної поведінки щодо використання об'єктів права інтелектуальної власності і спрямовані на впорядкування існуючих суспільних відносин в межах норм адміністративного права.

Правоохоронні правовідносини відіграють найбільш важливу роль у юрисдикційній діяльності уповноважених органів публічної адміністрації і пов'язані з реалізацією правоохоронної функції адміністративного права.

За складом учасників це можуть бути відносини як між усією системою органів публічної адміністрації, так й іншими публічними і приватними органами, а також відносини, де обов'язковою стороною є посадова особа органу публічної адміністрації, з іншої сторони - громадянин, суб’єкт господарської діяльності (юридична особа, фізична особа підприємець), так і за станом взаємної підпорядкованості суб'єктів, що беруть участь у правовідносинах.

За сферою виникнення - це 1) різноманітні відносини у сфері діяльності органу (органів) публічної адміністрації, 2) ті, що знаходяться за межами їхньої діяльності.

Гарантії як елемент адміністративноправового забезпечення слід розглядати як передбачений чинним законодавством комплекс правових засобів впливу, за допомогою яких забезпечується реалізація суспільних відносин у сфері охорони прав суб'єктів інтелектуальної власності, що випливають із загально-правових гарантій (конституційні гарантії) права кожного володіти, користуватися і розпоряджатися своєю власністю, результатами своєї інтелектуальної, творчої діяльності; держава гарантує захист інтелектуальної власності, авторських прав, моральних і матеріальних інтересів, що виникають у зв’язку з різними видами інтелектуальної діяльності.

Отже, одним із важливих елементів адміністративно-правового забезпечення $€$ гарантування держави в особі органів публічної адміністрації забезпечення охорони суб'єктивних прав та законних інтересів правовласників та інших учасників правовідносин у сфері інтелектуальної власності.

Висновки. Безумовно, наведений вище перелік певних видів адміністративно-правових відносин у досліджуваній сфері не вичерпує всієї повноти проблематики адміністративно-правового забезпечення охорони прав суб'єктів інтелектуальної власності. Однак, поставивши за мету розкриття поняття та структури адміністративно-правового забезпечення охорони прав суб'єктів інтелектуальної власності, автори надають власне визначення поняття «адміністративноправове забезпечення охорони прав суб'єктів інтелектуальної власності», під яким слід розуміти регламентовану адміністративноправовими нормами діяльність публічної адміністрації, їх посадових осіб, уповноважених забезпечити конституційні гарантії охорони та захисту прав суб'єктів інтелектуальної власності, права та інтереси інших учасників правовідносин у сфері інтелектуальної власності.

До структури адміністративно-правового забезпечення охорони прав суб'єктів інтелектуальної власності слід віднести такі елементи: об'єкт адміністративно-правового забезпечення - суспільні відносини у сфері охорони права інтелектуальної власності; суб'єктів адміністративно-правового забезпечення у сфері охорони права інтелектуальної власності - органи публічної адміністрації, наділені владними повноваженнями, правами та обов'язками, що встановлені адміністративно-правими нормами; норми права - адміністративно-правові норми, що являють собою різновид правових норм, які регулюють суспільні відносини у сфері охорони права інтелектуальної власності, виконують одну з основних функцій щодо забезпечення охорони особистого немайнового та майнового права інтелектуальної власності, захисту суб'єктів господарської діяльності та прав споживачів; адміністративно-правові відносини (регулятивні правовідносини; правоохоронні правовідносини; за складом учасників; за сферою виникнення; за станом взаємної підпорядкованості суб'єктів) відображають вплив адміністративно-право- 
вих норм на суб'єктів та об'єкти публічного управління у сфері охорони права інтелектуальної власності, виникають із настанням певних, передбачених адміністративно-правовими нормами юридичних фактів; гарантії як елемент адміністративно-правового забезпечення - передбачений чинним законодавством комплекс правових засобів впливу, за допомогою яких забезпечується реалізація суспільних відносин у сфері охорони інтелектуальної власності.

\section{Список використаних джерел:}

1. Світличний О. П. Право інтелектуальної власності : підручник. 2-ге вид., змін. і доп. Київ: НУБіП України, 2017. 355 с.

2. Потоцький М. Ю. Правове регулювання інтелектуальної власності в Україні: загальнотеоретичне дослідження : автореф. дис. ... канд. юрид. наук. Харків, 2009. 21 с
3. Комаров С. А. Механизмы правового воздействия. Теория государства и права: курс лекиий. Саранск, 1994. 314 c.

4. Малько А. В., Матузов Н. И. Теория государства и права. Москва : Юристъ, 1996. 672 с.

5. Римарчук Г. С. Адміністративно-правове забезпечення права інтелектуальної власності в Україні : автореф. дис. ... канд. юрид. наук. Львів, 2013. 20 с.

6. Світличний О.П. Суб'єкти публічної адміністрації: сучасний вимір. Службове право: витоки, сучасність та перспективи розвитку : колективна монографія / за заг. ред. Т. О. Коломоєць, В. К. Колпакова. Запоріжжя: Видавничий дім «Гельветика», 2017. С. 205-217.

7. Теория государства и права : учебник для юрид. вузов и факультетов / под ред. С. С. Алексеева. Москва : БЕК, 1998. 453 с.

8. Адміністративне право України: Академічний курс : підручник. у 2-х т. Т. 1. Загальна частина / ред. колегія: В. Б. Авер'янов (голова) та ін. Київ : ТОВ «Видавництво «Юридична літератуpa», 2007. 592 c

The article is devoted to the concept, the structure of administrative and legal support for the protection of intellectual property rights. The lack of theoretical generalizations and relevant practical recommendations adversely affect the formation and development of the science of administrative law, the protection of personal non-property and (or) property rights of subjects of intellectual property rights. Accordingly, the lack of a basic theory of administrative-legal support for the protection of intellectual property rights, the modern vision of the development of public relations in the research field have not yet received their scientific embodiment.

Constitutional law plays a leading role in regulating relations in the field of protection of intellectual property rights. Personal non-property and property rights of intellectual property are subject to legal protection by private and public law, with civil and administrative law, two fundamental branches of national law, playing a leading role. All this is reflected in the dispositive and imperative method of legal regulation, which are the most common methods of legal regulation in the field of research.

Attention is drawn to the fact that the administrative and legal support of public relations in the field of protection of the rights of intellectual property is a specific governmental activity of public administration bodies, their officials, who are vested with authority in the field of intellectual property protection. Such public bodies in the field of research are first of all the Ministry of Economic Development and Trade of Ukraine, Ukrpatent, AMCU and other authorized public administration bodies, which are empowered to implement, protect and develop relations in the field of intellectual property protection. Public administration activities involve the use of administrative and legal norms, which are a kind of legal norms and play an important role in the regulation of public relations in the field of protection of intellectual property rights, and performs one of the main functions in ensuring the protection of the subjective rights of the owners of intellectual property rights. property, protection of business entities, rights and legitimate interests of consumers. It is particularly important to identify areas of influence of legal regulation and implementation of administrative law by public administration bodies.

Particular attention is paid to the content and structure of administrative and legal support, the structure is revealed and the author defines the concept of „administrative and legal support”.

Key words: subjects, protection, rights, intellectual property, concepts, administrative and legal regulation, structure. 